\title{
Grouping of Water Supply-and-Demand Structure in the Yellow River Basin of China: Focusing on Balance between Groundwater and Surface-water
}

\author{
Toshiaki Ichinose ${ }^{1, *}$, Kai Liu $^{2}$, Akio Onishi ${ }^{3}$ and Feng Shi ${ }^{4}$ \\ 1 Centre for Social and Environmental Systems Research, National Institute for Environmental \\ Studies (NIES)/Graduate School of Environmental Studies, Nagoya University, NIES 16-2 Onogawa, \\ Tsukuba-City, Ibaraki 305-8506, Japan \\ 2 Graduate School of Life and Environmental Sciences, University of Tsukuba, Tsukuba-City, \\ Ibaraki 305-8572, Japan \\ 3 School of Data Science, Yokohama City University, Yokohama City, Kanagawa 236-0027, Japan \\ 4 The Institute of Science and Technology for Development of Shandong, Jinan 250000, China \\ * Correspondence: toshiaki@nies.go.jp; Tel.: +81-29-850-2598
}

Received: 21 May 2019; Accepted: 17 July 2019; Published: 23 July 2019

\begin{abstract}
The research purpose of this study was to uncover the grouping of the water supply-and-demand structure in the Yellow River Basin (YRB) of China, focusing on the balance between groundwater and surface-water. Comparing the structure of water usage and the structure of groundwater usage estimated by previous studies in each region, 35 municipalities were selected and they were classified into 12 catchments in focusing on the geographical location and the similarity of the shape of the structure of water supply-and-demand. In the upper reaches, surface-water is mainly used and the share of agricultural usage is small, therefore, seasonal variability of groundwater usage is small. On the other hand, in the middle and the lower reaches, the share of groundwater is large and the share of agricultural usage is large, therefore, seasonal variability of groundwater usage is large. Especially, these characteristics are obvious in the Loess Plateau. In addition, surface-water is mainly used again in the lowermost reaches. The results qualitatively identify the spatial pattern of the classification of water supply-and-demand structure and investigate the geographical heterogeneity within each catchment. Performing a GIS (Geographic Information System) -based estimation is meaningful for grasping the geospatial pattern of water supply-and-demand structure and for providing an area-by-area report of the situation of the water resource usage. It is hoped that this study serves as an academic reference for optimizing the water resource management and for providing some policy recommendations on resource's sustainability by using a GIS-based approach.
\end{abstract}

Keywords: groundwater; surface-water; water supply-and-demand structure; Yellow River Basin

\section{Introduction}

Many problems are currently recognized in relation to the development and use of water in the Yellow River Basin (YRB). Most importantly, the amount of water is inadequate, despite the development of large-scale water projects in recent decades. There has been a marked decline in water volumes since the 1980s because of a succession of dry seasons. As there is now less usable surface-water, groundwater is being extracted on a large scale in the plains regions. As a result, groundwater levels have drastically declined over large areas. The conflicts arising from unbalanced supply-and-demand of water are becoming more acute in arid and semi-arid regions that have inadequate amounts of water. Because groundwater extraction is now excessive over $52 \%$ of the YRB, cultivation is becoming more difficult, and deep groundwater, such as fossil water that has been stored for as long as 10,000 years, is being exploited. In addition, rapidly growing cities and industries are putting pressure on the 
availability of water for use in the natural environment and agriculture. Moreover, even with these growing needs for water for industrial and agricultural uses, the problem of wasteful use of water remains severe. Meanwhile, water quality is deteriorating.

In the YRB, the annual per capita water resource is around $580 \mathrm{~m}^{3}$, which is $6 \%$ of the global average and $24 \%$ of the average in China [1,2]. However, total water demand in the basin has been continuously increasing with the increasing population, expansion of irrigated agricultural land, and increasing industrialization and urbanization. The consumption has grown from $27.1 \mathrm{Gm}^{3}$ in 1980 to an annual average of over $40 \mathrm{Gm}^{3}$ by the end of 2008 [3].

In this context, it is important to understand the water supply-and-demand structures, where water supply is categorized by source (i.e., surface-water or groundwater) and demand (use) is allocated to three categories (household, industrial, and agricultural), in different areas of the basin and to identify how water can be used more rationally and efficiently [4-8]. As climates and hydrological conditions vary greatly in the different regions of the vast YRB, continuous monitoring has been conducted in the area and several researchers have attempted to clarify its hydrological cycles [9-12]. The main industry of the basin is agriculture, which requires irrigation, so changes in production activities and water usage conditions in agriculture have had significant effects on the balance of supply and demand of water over the entire basin [4-8]. Accordingly, studies are being actively pursued into production activities and water usage in particular regions [13-15].

Little research [16] has been conducted on the balance of water supply and demand across the entire basin or on the general management of water in this area in the 20th century. Existing data and other resources that could be used for such analyses are plentiful (e.g., Yellow River Conservancy Commission of the Ministry of Water Resources of the People's Republic of China, 1997-2000 [3]), but they are often difficult to obtain or use (e.g., they are geographically fragmented or lack uniformity in content and spatial precision), and the methodologies that have been used and model details are unclear in many respects. Zhang et al. (2006) [17] investigated 15 ecological regions (small basins within the YRB) to reveal regional water demand differences for instream flow and river ecological demand to develop the concept of minimum instream flow. Liu et al. (2012) [18] conducted analyses of water consumption, available water resources, and the balance between supply and demand for water resources, as well as an overall water resource security analysis for the YRB in 2009. However, the analytical methods used limited statistical interpretation and lacked geographic perspectives focusing on regional heterogeneity.

Onishi et al. [4-8] presented the characteristics of water supply-and-demand over the entire YRB, broken down by county and month, and proposed a framework for analyzing a series of hydrological cycles-extractions, losses, and returns-from upstream to downstream. To calculate flow volumes of the Yellow River, they used and verified flow rate observations. Unfortunately, the volumes of surface-water and groundwater were mixed together because of methodological limitations, and they could not separate the effects for the two types of water.

One of the problems with groundwater in the YRB is the imbalance in the spatial distribution of resource usage. With the objective of reproducing the behavior of groundwater levels in the YRB in a numerical simulation, Ichinose et al. (2009) [19] attempted to establish a spatial distribution of groundwater demand, for which specific data were not publicly available, in a high-resolution grid (Figures 1-4). Using the output of these distributions (groundwater usage), they conducted a numerical simulation with a three-dimensional groundwater circulation model (MODFLOW) that showed groundwater usage conditions that were similar to actual conditions. The calculations were based on satellite images of nocturnal light from the Earth's surface [20-22]. A methodology of downscaling published data referring to the satellite images of nocturnal light was employed in which groundwater extraction volumes for agriculture, industry, and household water, which are published at the provincial scale (but not at the municipality scale or in a higher resolution), were assigned to counties or grid cells (1120 $\mathrm{m}$ on a side). This is the key idea and hints for performing a GIS (Geographic Information System) -based estimation of water supply-and-demand structure in the YRB at the municipality scale, which will be explained in Section 2. 


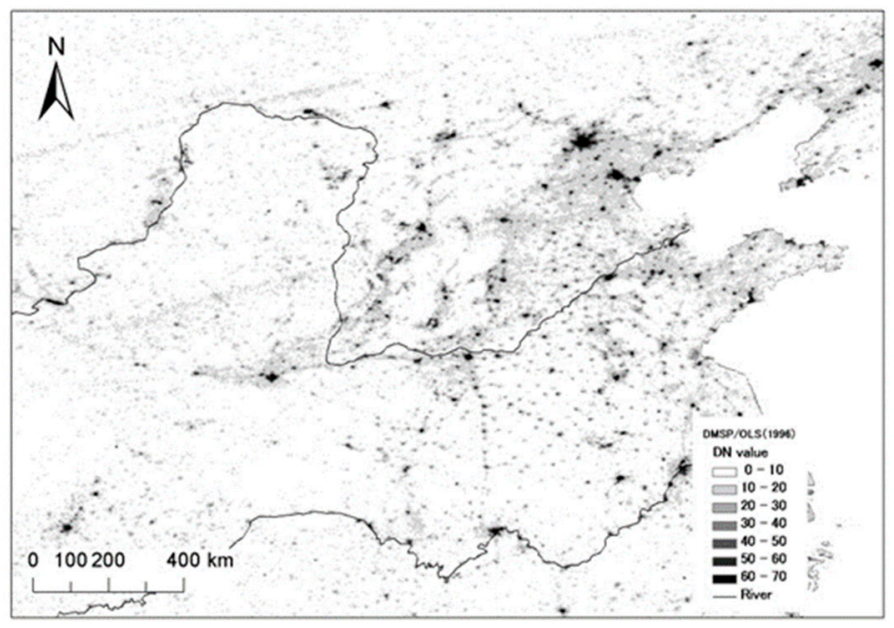

Figure 1. The Defense Meteorological Satellite Program/The Operational Linescan System (DMSP/OLS) nocturnal light intensity around Beijing in 1996 (Ichinose Eds., 2002 [20]; Ichinose et al., 2002 [21]). Resolution is around $1120 \mathrm{~m}$ [19].

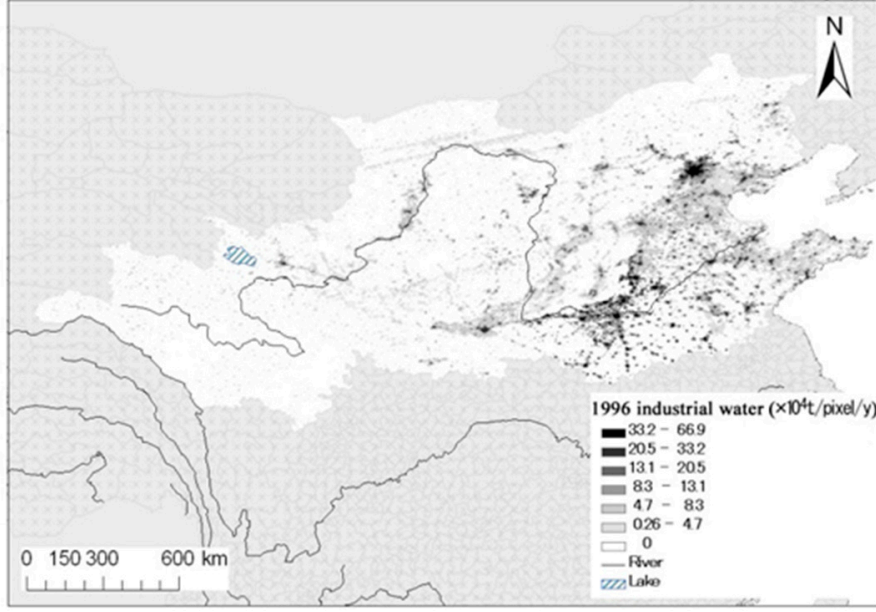

Figure 2. Withdrawal amount of groundwater as industrial water in the Yellow River Basin and the North China Plain in 1996 (around 1120-m pixel-base; ×104 t/pixel/y) [19].

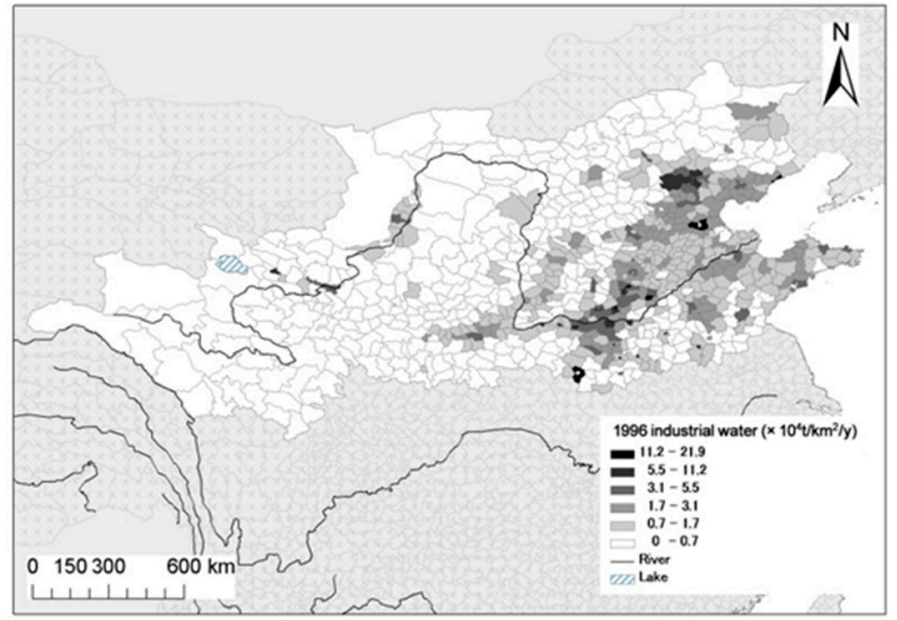

Figure 3. Withdrawal amount of groundwater as industrial water in the Yellow River Basin and the North China Plain in 1996, summarized in each polygon of the county $\left(\times 10^{4} \mathrm{t} / \mathrm{km}^{2} / \mathrm{y}\right)$ [19]. 

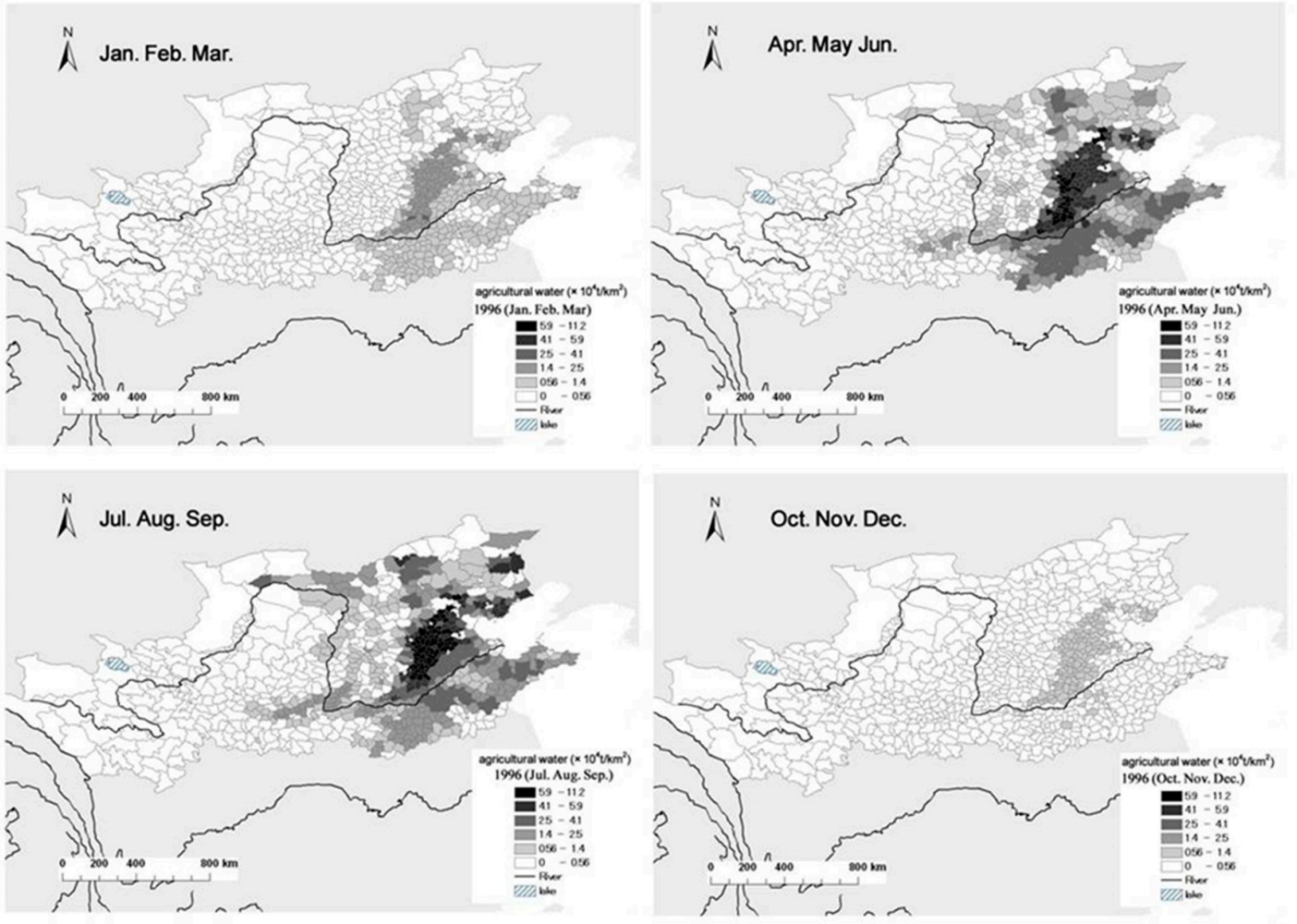

Figure 4. Withdrawal amount of groundwater as agricultural water in the Yellow River Basin and the North China Plain in 1996, considering irrigation demand for wheat and maize (for each season; $\times 10^{4} \mathrm{t} / \mathrm{km}^{2}$ ) [19].

However, the seasonal variation of agricultural water extraction volumes is very large. Therefore, to understand groundwater behavior, extraction scenarios that accurately reflect agricultural records must be established, rather than just setting up a simple irrigation model and estimating seasonal variations. When such extraction scenarios have been established, breakdowns of groundwater demand can then be established for individual regions, and seasonal water adaptation measures that account for interactions with surface-water can be considered. In the field of environmental informatics, Maqsood et al. (2003) [23], Luo et al. (2003) [24], Li et al. (2008) [25], and Guo et al. (2010) [26] focused on water resource management as it relates to water trading imbalances and climate change adaptation. Nevertheless, their examinations of water resource management did not include regional variations.

Data on the structure (categories of use) of surface-water usage are lacking, and actual usage is difficult to establish. In this study, we attempted to map surface-water usage by directly comparing the water usage estimated by Onishi et al. $(2006 a, 2006 b, 2007,2009,2012)$ [4-8] with the groundwater usage estimated by Ichinose et al. (2009) [19], region by region.

Our aims were to (1) overcome existing data limitations resulting from inconsistent governmental statistical data on water resources that are difficult to apply at the municipal scale; (2) reveal regional patterns of the water supply-demand structure in a new and innovative way and capture the geographical heterogeneity within each catchment by using a GIS-based approach; (3) better understand the balance between groundwater and surface-water use to optimize the water resource management in the future.

The rest of this paper is structured as follows. First, Section 2 explains the data production and methodological approach about the GIS-based estimation. Then, Section 3 highlights the results of water supply-and-demand structure in the YRB, by focusing on the balance between groundwater and surface-water usage and by revealing the comprehensive regional pattern of water supply-and-demand in each catchment. Last, Section 4 summarizes the key findings and conclusions and reaffirms the research significance. 


\section{Materials and Methods}

Onishi et al. (2006a, 2006b, 2007, 2009, 2012) [4-8] and Ichinose et al. (2009) [19] used data for the years 1997 and 1996, respectively. Ichinose et al. (2009) [19] presented maps in which groundwater usages for industry and households were expressed in a grid and aggregated by county. We used these same data for our analysis and selected 2009 as our target year, under the consideration of the consistency and integrity of our dataset. Basic data used in this study were not recent. This study's purpose was not an introduction of the current water resource issue in the YRB, but a trial on a new methodology of estimation under the public data limitation. This study, therefore, chose data of 1996 which all data are available for the framework of this study. This approach will be useful for other countries which have a similar situation of public data with China. As shown in Section 1, such water resource problem still remains in the YRB now. As mentioned in Section 1, how to perform a GIS-based estimation of water supply-and-demand in terms of surface-water and groundwater will be highlighted in this section.

Considering that Onishi et al. [4-8] had proposed a logical framework for analyzing a series of hydrological cycles and realizing a strict estimation of water supply-and-demand by county, this study followed Onishi's approach for achieving the calculation. Their model represented counties in the YRB as boxes, with water volumes obtained from rainfall and evaporation volumes, and with extraction and waste volumes estimated from levels of industrial and economic activity. They used industrial classifications and production values estimated from population statistics and gross domestic product (GDP) figures. They obtained water-use demand patterns for different crops, areas of irrigation, and other related information from published statistics and similar sources. They arranged the boxes from upstream to downstream over the entire basin and, by linking the boxes along the path of the river, established cascade relationships from upstream to downstream [4-8,27-29].

At this point, the volumes of surface-water and groundwater, i.e., the total amount of water supply, were mixed together because of methodological limitations, whereas our task was to separate the effects for the two types of water and to focus on the usage balance of groundwater and surface-water. Therefore, the next stage was to perform a GIS-based estimation of water supply-and-demand structure at the municipality scale in the context of this study.

Then, we selected 35 municipalities (see Table 1; Figure 5), covering most of the YRB, and assigned them to 12 catchments, according to their similarities in the structure of water supply-and-demand (Figure 6). For each of the 12 catchments, we compared the groundwater usage estimates of Ichinose et al. (2009) [19] (e.g., Figures 2-4) with the water usage estimates of Onishi et al. (2006a, 2006b, 2007, $2009,2012)[4-8]$. Onishi's data were estimated by county, so we similarly aggregated the data for the municipalities. The surface-waters in the catchments do not flow out to the ocean (i.e., they are part of the inner watershed) in the central part of the basin (Figure 5). To evaluate the seasonal variability of groundwater use, we applied a ratio of the peak value among the four seasons of agricultural use to total industrial and household usage over a 3-month period (see Table 1). The ratio categories were defined as follows: $<10 \%$, low; $10 \%$ to $100 \%$, medium-low; $100 \%$ to $200 \%$, medium; $200 \%$ to $400 \%$, medium-high; and $>400 \%$, high.

Table 1. Water supply-and-demand structures of each catchment.

\begin{tabular}{cccc}
\hline Catchments & $\begin{array}{c}\text { Municipalities (area: } \\
\mathbf{k m}^{\mathbf{2}} \text { ) }\end{array}$ & $\begin{array}{c}\text { Seasonal Variability } \\
\text { of Groundwater }\end{array}$ & Agricultural Water \\
\hline $\begin{array}{c}\text { Uppermost Reaches of } \\
\text { the Yellow River } \\
\text { (Qinghai Province) }\end{array}$ & $\begin{array}{c}\text { Xining }(3400), \\
\text { Haidong }(18,006)\end{array}$ & low & $\begin{array}{c}\text { Surface-water } \\
\text { mainly }\end{array}$ \\
\hline $\begin{array}{c}\text { Upper Reaches of the } \\
\text { Yellow River (Gansu } \\
\text { Province) }\end{array}$ & $\begin{array}{c}\text { Lanzhou }(12,600), \\
\text { Baiyin }(20,400), \\
\text { Linxia }(8209)\end{array}$ & medium-low & $\begin{array}{c}\text { Surface-water } \\
\text { mainly }\end{array}$ \\
\hline
\end{tabular}


Table 1. Cont.

\begin{tabular}{|c|c|c|c|c|}
\hline Catchments & $\begin{array}{l}\text { Municipalities (area: } \\
\text { km²) }^{2}\end{array}$ & $\begin{array}{l}\text { Seasonal Variability } \\
\text { of Groundwater }\end{array}$ & Agricultural Water & Characteristics \\
\hline $\begin{array}{c}\text { Upper Reaches of the } \\
\text { Yellow River (Ningxia } \\
\text { Province) }\end{array}$ & $\begin{array}{l}\text { Yinchuan (3100), } \\
\text { Shizuishan }(5310), \\
\text { Wuzhong }(27,068)\end{array}$ & medium-low & $\begin{array}{l}\text { Surface-water } \\
\text { mainly }\end{array}$ & Rice \\
\hline $\begin{array}{l}\text { Middle Reaches of the } \\
\text { Yellow River (Inner } \\
\text { Mongolia Province) }\end{array}$ & $\begin{array}{c}\text { Hohhot }(17,200), \\
\text { Baotou }(27,700), \\
\text { Ordos }(87,428), \\
\text { Bayannur }(41,021)\end{array}$ & high & $\begin{array}{l}\text { Surface-water } \\
\text { mainly }\end{array}$ & \\
\hline $\begin{array}{l}\text { Lower Reaches of the } \\
\text { Yellow River (He'nan } \\
\text { Province) }\end{array}$ & $\begin{array}{l}\text { Luoyang }(13,799) \text {, } \\
\text { Sanmenxia }(10,141)\end{array}$ & medium-high & $\begin{array}{l}\text { Groundwater } \\
\text { mainly }\end{array}$ & \\
\hline $\begin{array}{c}\text { Lowermost Reaches of } \\
\text { the Yellow River } \\
\text { (Shandong Province) }\end{array}$ & $\begin{array}{c}\text { Ji'nan (5215), } \\
\text { Tai'an (7692), } \\
\text { Dongying (6757) } \\
\end{array}$ & medium & $\begin{array}{l}\text { Surface-water } \\
\text { mainly }\end{array}$ & \\
\hline $\begin{array}{c}\text { Dividing Region } \\
\text { between the Yellow } \\
\text { River and the Wei River } \\
\text { (Gansu Province, } \\
\text { Ningxia Province) }\end{array}$ & $\begin{array}{l}\text { Dingxi }(19,604), \\
\text { Guyuan }(16,783)\end{array}$ & medium & $\begin{array}{l}\text { Surface-water } \\
\text { mainly }\end{array}$ & $\begin{array}{l}\text { Ground mainly, } \\
\text { excl. agriculture }\end{array}$ \\
\hline $\begin{array}{l}\text { Upper Reaches of the } \\
\text { Wei River (Gansu } \\
\text { Province, Shaanxi } \\
\text { Province) }\end{array}$ & $\begin{array}{c}\text { Tianshui }(13,800), \\
\text { Pingliang }(11,225), \\
\text { Qingyang }(24,209), \\
\text { Baoji }(15,013)\end{array}$ & medium & Surface:Ground 3:1 & \\
\hline $\begin{array}{c}\text { Lower Reaches of the } \\
\text { Wei River (Shaanxi } \\
\text { Province) }\end{array}$ & $\begin{array}{c}\text { Xi'an }(9107), \\
\text { Xianyang }(10,200), \\
\text { Tongchuan }(3900)\end{array}$ & medium-high & Surface:Ground 3:1 & $\begin{array}{l}\text { Ground mainly } \\
\text { (Tongchuan) }\end{array}$ \\
\hline $\begin{array}{l}\text { Middle Reaches of the } \\
\text { Yellow River (Shaanxi } \\
\text { Province) }\end{array}$ & $\begin{array}{c}\text { Yan'an }(37,089), \\
\text { Yulin }(43,493), \\
\text { Weinan }(12,283)\end{array}$ & medium-high & $\begin{array}{l}\text { Groundwater } \\
\text { mainly }\end{array}$ & $\begin{array}{l}\text { Depending Surface } \\
\text { (Weinan) }\end{array}$ \\
\hline $\begin{array}{l}\text { Middle Reaches of the } \\
\text { Yellow River (Shanxi } \\
\text { Province) }\end{array}$ & $\begin{array}{l}\text { Taiyuan (7000), } \\
\text { Lueliang (21,144), } \\
\text { Jinzhong (8534) }\end{array}$ & medium-high & Surface:Ground 2:1 & $\begin{array}{l}\text { Ground mainly } \\
\text { (Lueliang) }\end{array}$ \\
\hline $\begin{array}{c}\text { Catchments by Southern } \\
\text { Shanxi (around the Fen } \\
\text { River) }\end{array}$ & $\begin{array}{l}\text { Yuncheng }(13,968) \text {, } \\
\text { Linfen }(20,279), \\
\text { Jincheng }(7749)\end{array}$ & high & Surface:Ground 2:1 & $\begin{array}{l}\text { Ground mainly } \\
\quad \text { (Linfen) }\end{array}$ \\
\hline
\end{tabular}

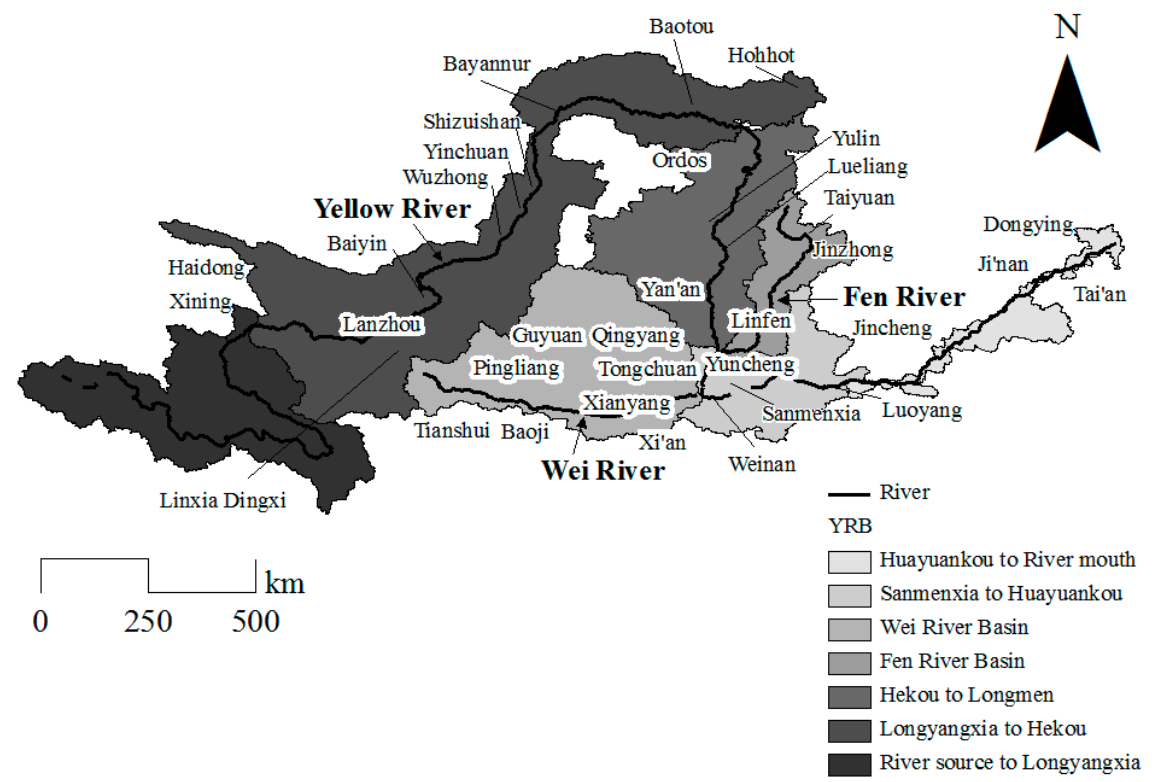

Figure 5. Thirty-five municipalities, which covered almost the entire basin of the Yellow River. Source of the map: Masutomi et al. (2009) [30]. 

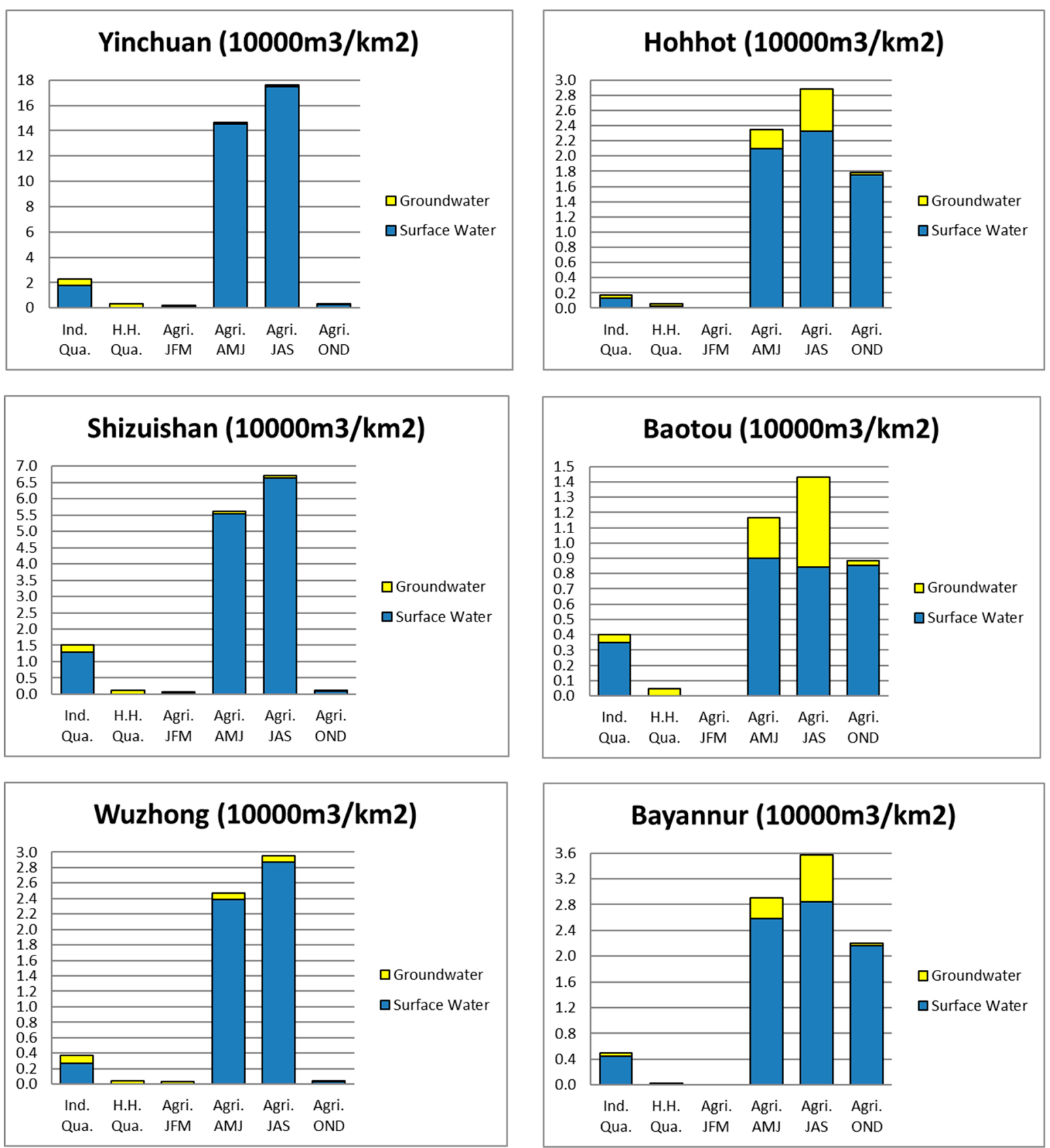

Upper reaches of the Yellow R.

(Ningxia shown in pink on the map

Middle reaches of the Yellow R.

(Inner Mongolia shown in black on

shown in the last of this figure)

the map shown in the last of this figure)

Figure 6. Cont. 

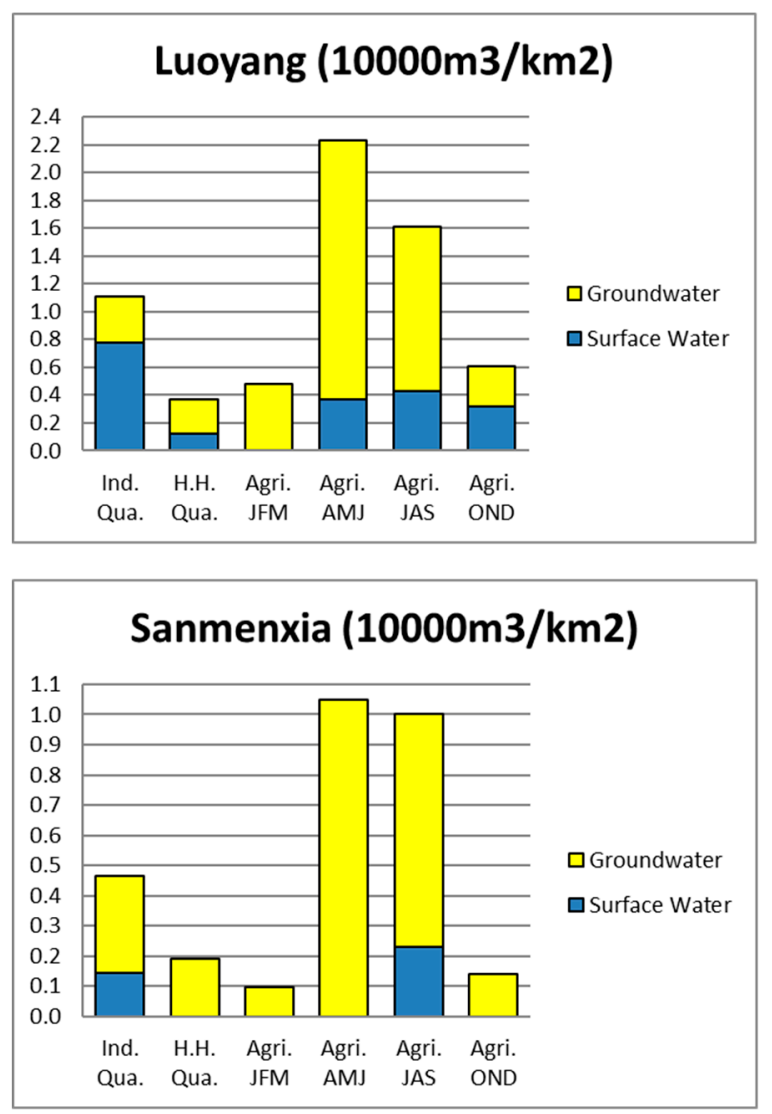

$\begin{array}{cccccc}\text { Ind. } & \text { H.H. } & \text { Agri. } & \text { Agri. } & \text { Agri. } & \text { Agri. } \\ \text { Qua. } & \text { Qua. } & \text { JFM } & \text { AMJ } & \text { JAS } & \text { OND }\end{array}$

促

Lower reaches of the Yellow R.

(He'nan shown in green on the map

shown in the last of this figure)
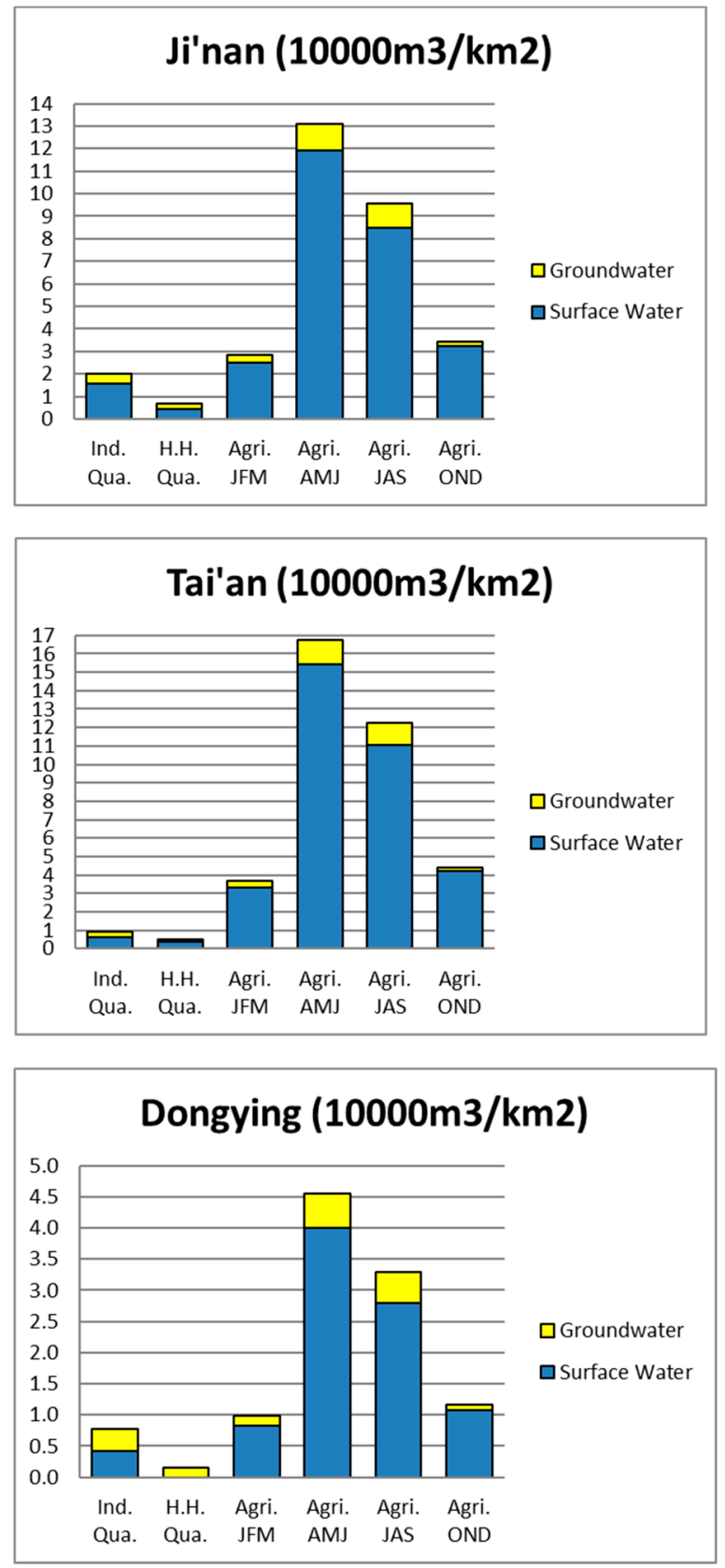

Lowermost reaches of the Yellow R.

(Shandong shown in light blue on the map shown in the last of this figure)

Figure 6. Cont. 

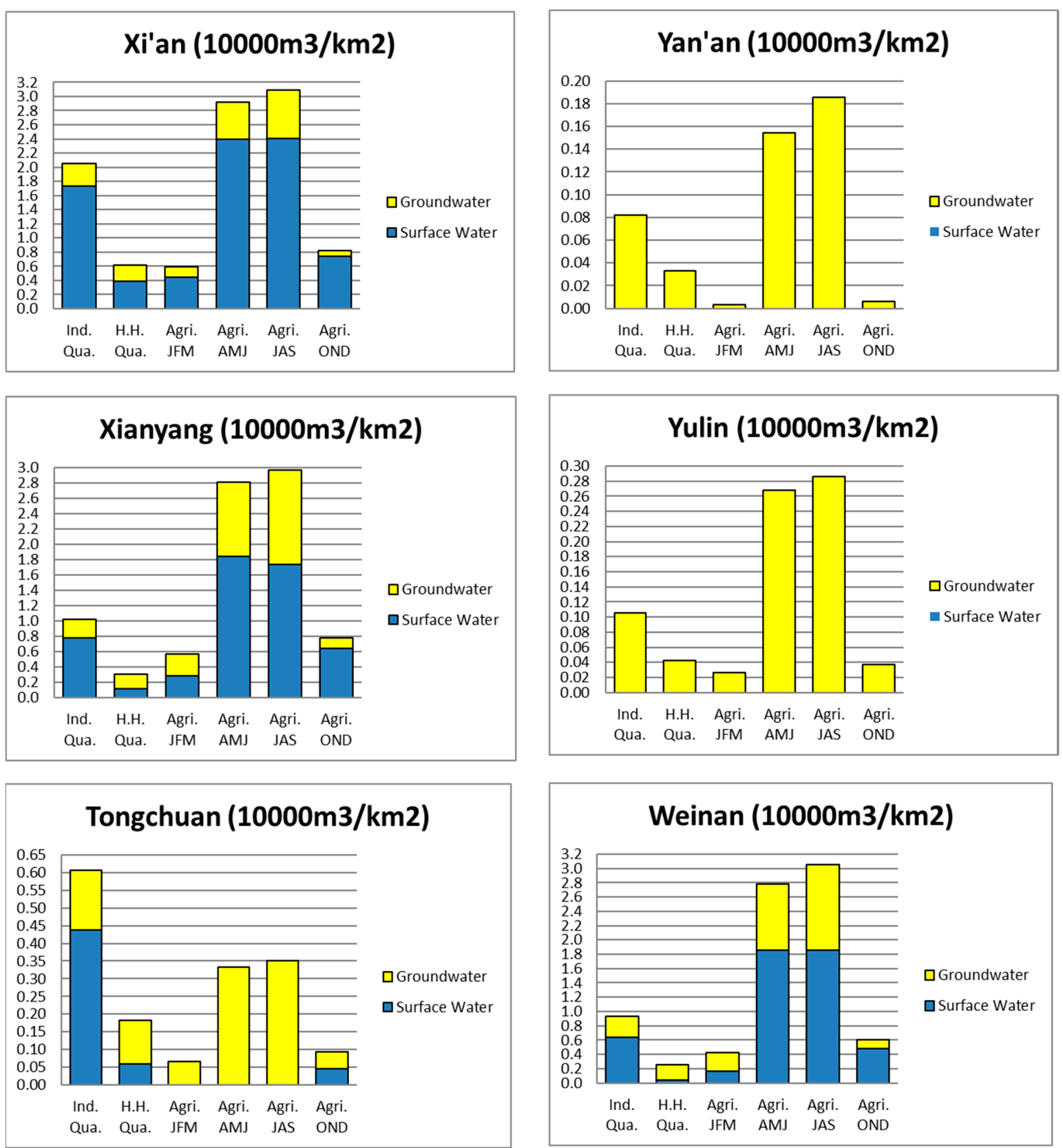

Upper reaches of the Wei R.

Middle reaches of the Yellow R.

(Shaanxi shown in red on the

(Shaanxi shown in purple on the map shown in the last of this figure) map shown in the last of this figure)

Figure 6. Cont. 

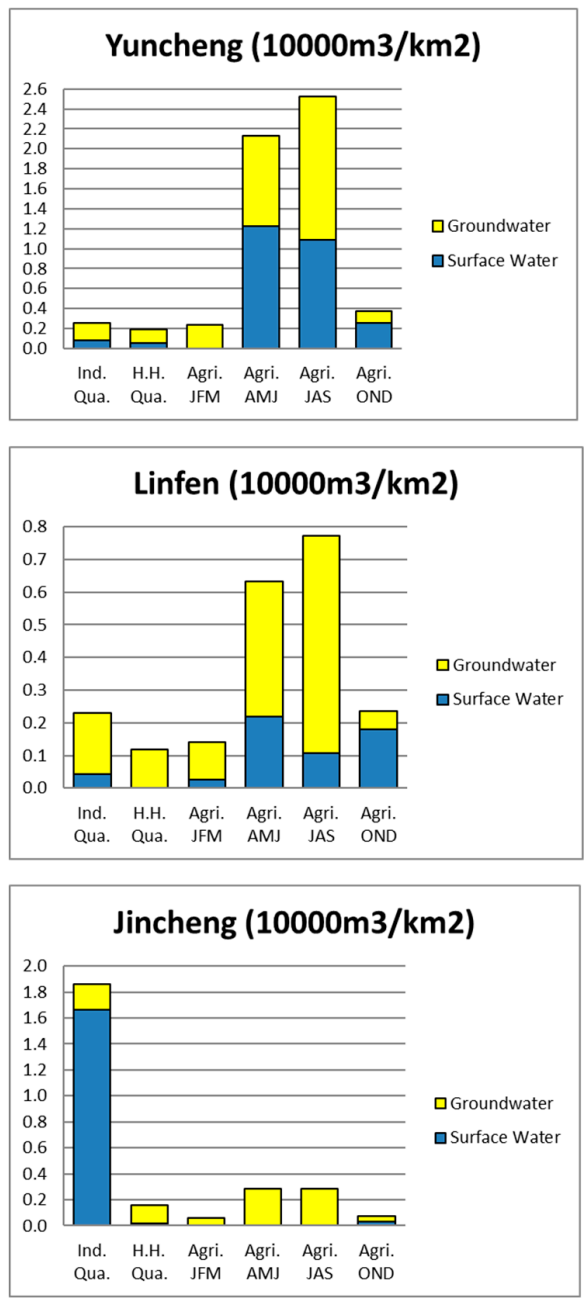

Catchments by southern Shanxi (around the Fen river shown in blue on the map shown in the last of this figure)

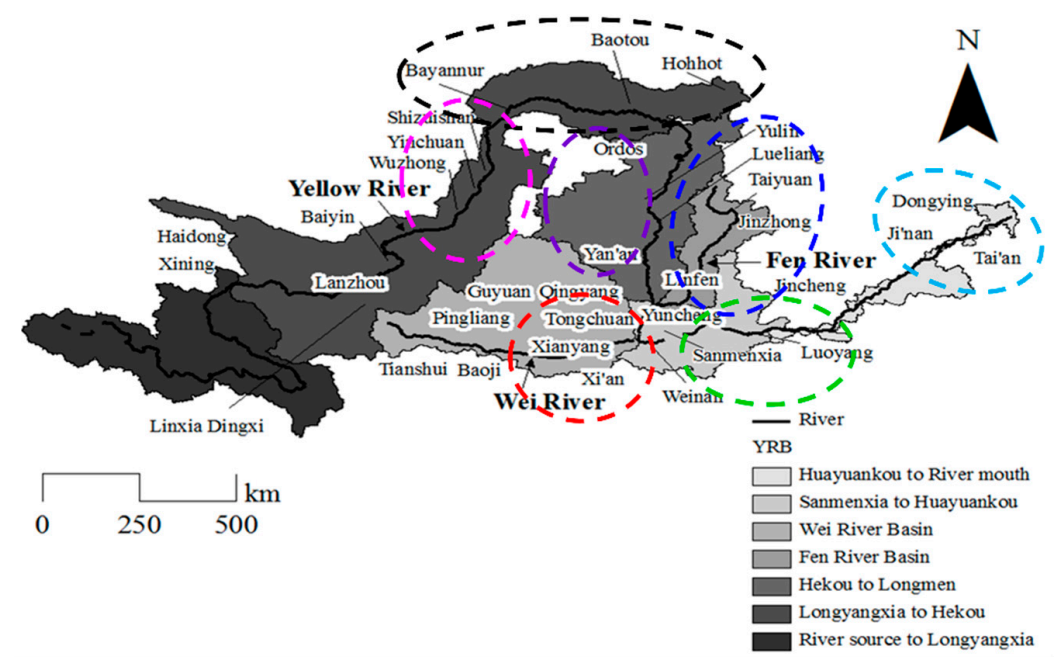

Figure 6. Season-series water supply-and-demand structures (by categories) of representative seven catchments among the 12 catchments in 2009. Note: Representative seven catchments are indicated in colored rounds, corresponding to the results of bar graphs. Ind.: Industrial, H.H.: Household, Agri.: Agricultural. Qua.: three months, JFM: January to March, AMJ: April to June, JAS: July to September, OND: October to December. 
On the other hand, the selected 35 municipalities did have spatiotemporal diversity, regional heterogeneity and characteristic complexity. The reason why we selected the YRB as our study area should also be noted. First, based on our face-to-face investigations toward the local residents, the urban water usage and agricultural water usage have numerous regional characteristics and seasonal variability (cf. Ichinose et al., 2009 [19]). For example, in the lower reaches of the YRB, e.g., Zhengzhou and Ji'nan, the surface-water is the main supply; in Luoyang, the surface-water is under a unified scheduling and management though the governmental facilities (e.g., dam); in Xi'an, both groundwater and surface-water are fully used for satisfying the urban residents' needs; however in middle reaches (e.g., Yan'an, Yulin), there is a shortage of surface-water and the groundwater is the major resource for the agricultural irrigation. Furthermore, it is also meaningful to consider the seasonal variability of the water demand, towards the goal of the development of intelligent agricultural irrigation and water management systems. Based on the above-mentioned, this study aimed to reveal regional patterns of the water supply-demand structure and to capture the geographical heterogeneity within each catchment in the entire YRB, by considering the balance of groundwater and surface-water and the seasonal variability of water usage by categories, i.e., industry, household and agriculture.

\section{Results}

The results are discussed below and summarized in Figure 6 and Table 1.

\subsection{Uppermost Reaches of the Yellow River (Qinghai Province)}

Xining $\left(3400 \mathrm{~km}^{2}\right)$ and Haidong $\left(18,006 \mathrm{~km}^{2}\right)$ are located in this catchment. Livestock farming is common in this area, but water usage in industry and households is several times that in agriculture, so seasonal variations in groundwater usage are at the low level. In Xining, the peak agricultural usage was a little less than $0.05 \times 10^{4} \mathrm{~m}^{3} / \mathrm{km}^{2}$ (all values are per 3-month period unless otherwise specified), while non-agricultural usage was slightly greater than $0.45 \times 10^{4} \mathrm{~m}^{3} / \mathrm{km}^{2}$. Agricultural demand was greater than $2 \times 10^{4} \mathrm{~m}^{3} / \mathrm{km}^{2}$ from spring to summer, almost all of which was supplied from surface-water. About three times as much surface-water as groundwater was used for non-agricultural purposes.

\subsection{Upper Reaches of the Yellow River (Gansu Province)}

Lanzhou $\left(12,600 \mathrm{~km}^{2}\right)$, Baiyin $\left(20,400 \mathrm{~km}^{2}\right)$, and Linxia $\left(8209 \mathrm{~km}^{2}\right)$ are located in this catchment. Usage in industry and households was at about the same level as the agricultural peak usage (spring), and there was little seasonal variation in groundwater usage (at the middle-low level). In Lanzhou, the peak agricultural usage was slightly less than $0.1 \times 10^{4} \mathrm{~m}^{3} / \mathrm{km}^{2}$, while non-agricultural usage was just under $0.2 \times 10^{4} \mathrm{~m}^{3} / \mathrm{km}^{2}$. Agricultural demand was greater than $1 \times 10^{4} \mathrm{~m}^{3} / \mathrm{km}^{2}$ from spring (mainly for wheat) to summer (maize), almost all of which was supplied from surface-water. About five times as much surface-water as groundwater was used for non-agricultural purposes.

\subsection{Upper Reaches of the Yellow River (Ningxia Province)}

Yinchuan $\left(3100 \mathrm{~km}^{2}\right)$, Shizuishan $\left(5310 \mathrm{~km}^{2}\right)$, and Wuzhong $\left(27,068 \mathrm{~km}^{2}\right)$ are located in this catchment. Usage in industry and households was about two to three times the agricultural peak, and there was little seasonal variation in groundwater usage (at the middle level). In Yinchuan, the peak agricultural usage was slightly less than $0.15 \times 10^{4} \mathrm{~m}^{3} / \mathrm{km}^{2}$, whereas non-agricultural usage was just over $0.7 \times 10^{4} \mathrm{~m}^{3} / \mathrm{km}^{2}$. Agricultural usage was around $15 \times 10^{4} \mathrm{~m}^{3} / \mathrm{km}^{2}$ from spring to summer, almost all of which was supplied from surface-water. In Ichinose et al. (2009) [19], this region was modeled with wheat being raised in the spring and maize in the summer. However, as noted in Onishi et al. (2006a, 2006b, 2007, 2009, 2012) [4-8] and other studies, the Qingtongxia Irrigation District is a well-known rice-producing area. Accordingly, surface-water usage was assumed to be consistent with the production of rice. About three times as much surface-water as groundwater was used for non-agricultural purposes. 


\subsection{Middle Reaches of the Yellow River (Inner Mongolia Province)}

Hohhot $\left(17,200 \mathrm{~km}^{2}\right)$, Baotou $\left(27,700 \mathrm{~km}^{2}\right)$, Ordos $\left(87,428 \mathrm{~km}^{2}\right)$, and Bayannur $\left(41,021 \mathrm{~km}^{2}\right)$ are located in this catchment. Usage in industry and households was much smaller than the agricultural peak, so the seasonal variation in groundwater usage was at a high level. In Bayannur, the agricultural peak was just over $0.7 \times 10^{4} \mathrm{~m}^{3} / \mathrm{km}^{2}$, while non-agricultural usage was slightly less than $0.1 \times 10^{4} \mathrm{~m}^{3} / \mathrm{km}^{2}$. There was a demand for water in agriculture from spring to autumn (peaking at a little more than $3.5 \times 10^{4} \mathrm{~m}^{3} / \mathrm{km}^{2}$ in the summer), almost all of which was supplied from surface-water. Perhaps because the areas of the municipalities are very large, the water demand volumes per unit area were small as compared to the case of Ningxia, which has similarly severe aridity and large evaporation volumes. About five times as much surface-water as groundwater was used for non-agricultural purposes.

\subsection{Lower Reaches of the Yellow River (He'nan Province)}

Luoyang $\left(13,799 \mathrm{~km}^{2}\right)$ and Sanmenxia $\left(10,141 \mathrm{~km}^{2}\right)$ are located in this catchment. Ordinarily, these municipalities would be regarded as a part of the middle Yellow River, but we included them in the lower reaches because of their relative location to other catchments. Usage in industry and households were smaller than the agricultural peak, so the seasonal variation in groundwater usage was at the medium-high level. In Luoyang, the peak agricultural usage was slightly greater than $1.8 \times 10^{4} \mathrm{~m}^{3} / \mathrm{km}^{2}$, while non-agricultural usage was just over $0.5 \times 10^{4} \mathrm{~m}^{3} / \mathrm{km}^{2}$. There was demand for water in agriculture from spring (mainly for wheat) to summer (maize) (peaking at a little more than $2.2 \times 10^{4} \mathrm{~m}^{3} / \mathrm{km}^{2}$ in the spring), almost all of which was supplied from groundwater. The model in Ichinose et al. (2009) [19] appears to have closely portrayed actual agricultural conditions. About three times as much surface-water as groundwater was used for non-agricultural purposes.

\subsection{Lowermost Reaches of the Yellow River (Shandong Province)}

Ji'nan $\left(5215 \mathrm{~km}^{2}\right)$, Tai'an $\left(7692 \mathrm{~km}^{2}\right)$, and Dongying $\left(6757 \mathrm{~km}^{2}\right)$ are located in this catchment. Usage in industry and households was less than $20 \%$ of the agricultural peak, and the seasonal variation in groundwater usage was at the medium level. In Ji'nan, the peak agricultural usage was slightly less than $1.2 \times 10^{4} \mathrm{~m}^{3} / \mathrm{km}^{2}$, while non-agricultural usage was a little over $0.6 \times 10^{4} \mathrm{~m}^{3} / \mathrm{km}^{2}$. There was a high demand for water in agriculture from spring (mainly for wheat) to summer (maize) (peaking at about $13 \times 10^{4} \mathrm{~m}^{3} / \mathrm{km}^{2}$ in the spring), almost all of which was supplied from surface-water. About four times as much surface-water as groundwater was used for non-agricultural purposes.

\subsection{Dividing Region between the Yellow River and the Wei River (Gansu Province, Ningxia Province)}

Dingxi $\left(19,604 \mathrm{~km}^{2}\right)$ and Guyuan $\left(16,783 \mathrm{~km}^{2}\right)$ are located in this catchment. Usage in industry and households was less than $50 \%$ of the agricultural peak, and the seasonal variation in groundwater usage was at the medium level. In Guyuan, the peak agricultural usage was just over $0.2 \times 10^{4} \mathrm{~m}^{3} / \mathrm{km}^{2}$, while non-agricultural usage was slightly less than $0.15 \times 10^{4} \mathrm{~m}^{3} / \mathrm{km}^{2}$. Agricultural demand was about $1.7 \times 10^{4} \mathrm{~m}^{3} / \mathrm{km}^{2}$ from spring (mainly for wheat) to summer (maize), almost all of which was met from surface-water. Non-agricultural demand seemed to be almost entirely dependent on groundwater. In Dingxi, the dependency on groundwater was a bit greater. About five times as much surface-water as groundwater was used for non-agricultural purposes.

\subsection{Upper Reaches of the Wei River (Gansu Province, Shaanxi Province)}

Tianshui $\left(13,800 \mathrm{~km}^{2}\right)$, Pingliang $\left(11,225 \mathrm{~km}^{2}\right)$, Qingyang $\left(24,209 \mathrm{~km}^{2}\right)$, and Baoji $\left(15,013 \mathrm{~km}^{2}\right)$ are located in this catchment. Usage in industry and households was less than $60 \%$ of the agricultural peak, and the seasonal variation in groundwater usage was at the medium level. In Pingliang, the peak agricultural usage was about $0.2 \times 10^{4} \mathrm{~m}^{3} / \mathrm{km}^{2}$, while non-agricultural usage was slightly less than $0.1 \times 10^{4} \mathrm{~m}^{3} / \mathrm{km}^{2}$. Agricultural demand was about $0.6 \times 10^{4} \mathrm{~m}^{3} / \mathrm{km}^{2}$ from spring (mainly for wheat) to summer (maize), most of which was supplied from surface-water, in a ratio of about 3:1. About 
six times as much surface-water as groundwater was used for non-agricultural purposes, but the dependency on groundwater was a little greater in Baoji.

\subsection{Lower Reaches of the Wei River (Shaanxi Province)}

Xi'an $\left(9107 \mathrm{~km}^{2}\right)$, Xianyang $\left(10,200 \mathrm{~km}^{2}\right)$, and Tongchuan $\left(3900 \mathrm{~km}^{2}\right)$ are located in this catchment. Usage in industry and households was less than $100 \%$ of the agricultural peak, and the seasonal variation in groundwater usage was at the medium-high level. In Xianyang, the peak agricultural usage was slightly greater than $1.2 \times 10^{4} \mathrm{~m}^{3} / \mathrm{km}^{2}$, while non-agricultural usage was just over $0.4 \times 10^{4} \mathrm{~m}^{3} / \mathrm{km}^{2}$. Agricultural demand was slightly less than $3 \times 10^{4} \mathrm{~m}^{3} / \mathrm{km}^{2}$ from spring (mainly for wheat) to summer (maize), most of which was supplied from surface-water, in a ratio of about 3:1. About three times as much surface-water as groundwater was used for non-agricultural purposes. In Tongchuan, which is farther away from the Wei River than the other communities, agricultural water was mostly supplied from groundwater. It also appeared that industries predominantly used surface-water.

\subsection{Middle Reaches of the Yellow River (Shaanxi Province)}

Yan'an $\left(37,089 \mathrm{~km}^{2}\right)$, Yulin $\left(43,493 \mathrm{~km}^{2}\right)$, and Weinan $\left(12,283 \mathrm{~km}^{2}\right)$ are located in this catchment. Usage in industry and households was less than $40 \%$ of the agricultural peak, and the seasonal variation in groundwater usage was at the medium-high level. In Yulin, the peak agricultural usage was slightly greater than $0.45 \times 10^{4} \mathrm{~m}^{3} / \mathrm{km}^{2}$, while non-agricultural usage was slightly less than $0.2 \times 10^{4} \mathrm{~m}^{3} / \mathrm{km}^{2}$. Agricultural demand was a little less than $0.3 \times 10^{4} \mathrm{~m}^{3} / \mathrm{km}^{2}$ from spring (mainly for wheat) to summer (maize). It seems likely that agricultural usage was almost entirely supplied from groundwater, and non-agricultural demand was also supplied from groundwater. Weinan is closer to the Wei River, so its dependency on surface-water is greater.

\subsection{Middle Reaches of the Yellow River (Shanxi Province)}

Taiyuan $\left(7000 \mathrm{~km}^{2}\right)$, Lueliang $\left(21,144 \mathrm{~km}^{2}\right)$, and Jinzhong $\left(8534 \mathrm{~km}^{2}\right)$ are located in this catchment. Usage in industry and households was less than $100 \%$ of the agricultural peak, and the seasonal variation in groundwater usage was at the medium-high level. In Jinzhong, the peak agricultural usage was about $1 \times 10^{4} \mathrm{~m}^{3} / \mathrm{km}^{2}$, while non-agricultural usage was about $0.4 \times 10^{4} \mathrm{~m}^{3} / \mathrm{km}^{2}$. Agricultural demand was around $1.5 \times 10^{4} \mathrm{~m}^{3} / \mathrm{km}^{2}$ from spring (mainly for wheat) to summer (maize), most of which was supplied by surface-water, in a ratio of about 2:1. Non-agricultural demand was mainly met from groundwater. In Taiyuan, a substantial amount of surface-water was used for industry. In Lueliang, it seems likely that almost all water was supplied from groundwater.

\subsection{The Catchments in Southern Shanxi Province (around the Fen River)}

Yuncheng $\left(13,968 \mathrm{~km}^{2}\right)$, Linfen $\left(20,279 \mathrm{~km}^{2}\right)$, and Jincheng $\left(7749 \mathrm{~km}^{2}\right)$ are located in this catchment. Usage in industry and households was much smaller than the agricultural peak, and the seasonal variation in groundwater usage was at the high level. In Yuncheng, the peak agricultural usage was just over $1.4 \times 10^{4} \mathrm{~m}^{3} / \mathrm{km}^{2}$, while non-agricultural usage was about $0.3 \times 10^{4} \mathrm{~m}^{3} / \mathrm{km}^{2}$. Agricultural demand was around $2.3 \times 10^{4} \mathrm{~m}^{3} / \mathrm{km}^{2}$ from spring (mainly from wheat) to summer (maize), most of which was supplied by surface-water (the Yellow River), in a ratio of about 2:1. Non-agricultural volumes were small, and they appeared to be supplied from groundwater. In Linfen, where the flow of the Fen River is small, almost all of the water demand appeared to be supplied from groundwater. In Jincheng, apart from prominent industrial use of surface-water (the Yellow River), almost all water demand was met from groundwater, although the volumes withdrawn were small. 


\section{Discussion and Conclusions}

In this study, we aimed to reveal regional patterns of the water supply-demand structure in the Yellow River Basin and capture the geographical heterogeneity within each catchment to better understand the balance between the groundwater and surface-water use and to provide an academic reference for water resource management optimization.

In general, municipalities in the upper catchments depended on surface-water and the proportions used for agriculture were small, so seasonal variations in groundwater usage were small. In contrast, communities in the middle and lower catchments were much more dependent on groundwater and the proportions used for agriculture were large, so seasonal variations in groundwater usage was large. This tendency was particularly striking on the Loess Plateau. Municipalities in the lower catchments (i.e., farthest downstream) were mainly dependent on surface-water.

Despite having similar usage patterns of groundwater, differences were observed in the structures of water supply and demand, mainly because of the use of surface-water in some of the catchments. Differences in the water supply-and-demand structures were striking, particularly in the middle reaches, and they appeared to be primarily related to access to surface-water (i.e., the main rivers). Outside of agriculture, surface-water is primarily used by industry.

This research will contribute to the reasonable water resource management in the YRB through lending water among sources and municipalities (catchments) in cases of water resource shortage.

Author Contributions: Conceptualization, T.I.; data curation, K.L. and F.S.; formal analysis, T.I.; investigation, T.I., A.O. and F.S.; methodology, T.I.; project administration, T.I.; resources, A.O. and F.S.; software, L.K.; validation, A.O.; visualization, K.L.; writing—original draft, T.I.; writing—review and editing, T.I. and K.L.

Funding: This research was funded by NIES Research Project titled "Development of water demand and trade models for a global water resources model and their application to long term scenario analyses", grant number SR-104-2012.

Acknowledgments: The authors sincerely thank Mongshan Ee (Deakin University) and Kuninori Otsubo (Sophia University) for their contribution to the related work. The authors show their special thanks to many collaborators from China. The authors would also like to thank the editor and the anonymous reviewers for their constructive comments and suggestions.

Conflicts of Interest: The authors declare no conflicts of interest.

\section{References}

1. Japan Bank for International Cooperation. JBIC Research Paper; Japan Bank for International Cooperation: Tokyo, Japan, 2004. (In Japanese)

2. Ministry of Water Resources of the People's Republic of China. Public Report of Water Resources of China; Ministry of Water Resources of the People's Republic of China: Beijing, China, 1997-2000. (In Chinese)

3. Yellow River Conservancy Commission of the Ministry of Water Resources of the People's Republic of China. Public Report of Water Resources of Yellow River; Yellow River Conservancy Commission of the Ministry of Water Resources of the People's Republic of China: Zhengzhou, China, 1997-2008. (In Chinese)

4. Onishi, A.; Han, J.; Shirakawa, H.; Imura, H. Understanding seasonal and regional characteristics of water resource supply and demand structures in the Yellow River Basin. In Proceedings of the Eighth International Summer Symposium, Japan Society of Civil Engineers, Nagoya, Japan, 29 July 2006; pp. 343-346.

5. Onishi, A.; Imura, H.; Shirakawa, H.; Han, J. Grasp of seasonal and regional characteristics of water resource supply and demand structures in the Yellow River Basin. Environ. Syst. Res. 2006, 34, 611-622, (In Japanese with English abstract). [CrossRef]

6. Onishi, A.; Imura, H.; Han, J.; Shi, F.; Fukushima, Y. Socio-economic activities and the balance between water resource supply and demand in the Yellow River Basin, China. Water Energy Abstr. 2007, 315, 320-327.

7. Onishi, A.; Imura, H.; Shi, F.; Fang, W.; Han, J.; Fukushima, Y. Study on future water supply and demand in the Yellow River Basin of China based on scenario analysis. In From Headwaters to the Ocean: Hydrological Change and Watershed Management; CRC Press: Kyoto, Japan, 2009; pp. 459-464.

8. Onishi, A.; Shi, F.; Cao, X.; Okuoka, K.; Morisugi, M. Analysis of the spatial water demand and supply structures in the Yellow River Basin, China. J. Environ. Inf. Sci. 2012, 40, 89-100. 
9. Xu, Z.; Takeuchi, K.; Ishidaira, H.; Zhang, X. Sustainability analysis for Yellow River water resources using the system dynamics approach. Water Resour. Mgnag. 2002, 16, 239-261. [CrossRef]

10. Ao, T.; Takeuchi, K.; Ishidaira, H. On the method of generating artificial stream networks of large river basins and its effect on runoff simulation. Annu. J. Hydraul. Eng. 2001, 45, 139-144, (In Japanese with English abstract). [CrossRef]

11. Yang, D.; Herath, S.; Mushiake, K. A hillslope-based hydrological model using catchment area and width functions. Hydrol. Sci. J. 2002, 47, 49-65. [CrossRef]

12. Yang, D.; Li, C.; Hu, H.; Lei, Z.; Yang, S.; Kusuda, T.; Koike, T.; Mushiake, K. Analysis of water resources variability in the Yellow River of China during the last half century using historical data. Water Resour. Res. 2004, 40, W06502. [CrossRef]

13. Watanabe, T.; Hoshikawa, K. Water use and water balance of large irrigation schemes in the Yellow River Basin. In Proceedings of the 2nd International Workshop on Yellow River Studies, Kyoto, Japan, 8-10 November 2004; pp. 22-25.

14. Hoshikawa, K.; Nagano, T.; Donma, S.; Watanabe, T.; Fukushima, Y. Application of Irrigation Management Performance Assessment Model (IMPAM) to the Lower Seyhan Irrigation Project; ICCAP-Cappadocia Workshop: San Jose, CA, USA, 2004; pp. 93-96.

15. Hoshikawa, K.; Watanabe, T.; Fukushima, Y. Water balance modeling of large irrigation districts in the Yellow River Basin. In Proceedings of the 2nd International Workshop on Yellow River Studies, Kyoto, Japan, 8-10 November 2004; pp. 42-45.

16. World Bank. Sinclair Knight Merz and Egis Consulting Australia, the General Institute of Water Resources \& Hydropower Planning and Design. In China Agenda for Water Sector Strategy for North China; World Bank: Washington, DC, USA, 2001.

17. Zhang, Y.; Yang, Z.; Wang, X. Methodology to determine regional water demand for instream flow and its application in the Yellow River Basin. J. Environ. Sci. 2006, 18, 1031-1039. [CrossRef]

18. Liu, K.; Li, C.; Yang, X.; Hu, J.; Xia, X. Water resources supply-consumption (demand) balance analyses in the Yellow River Basin in 2009. Procedia Environ. Sci. 2012, 13, 1956-1965. [CrossRef]

19. Ichinose, T.; Harada, I.; Ee, M.; Otsubo, K. Estimation of groundwater resource demand in the Yellow River Basin, China. In From Headwaters to the Ocean: Hydrological Change and Watershed Management; CRC Press: Kyoto, Japan, 2009; pp. 477-482.

20. Ichinose, T.; Matsumura, K.; Nakaya, T.; Nakano, Y.; Elvidge, C. Estimation on regional intensity of economic activity in Asia: An application of nocturnal light images by DMSP. Proc. Symp. Glob. Environ. 2002, 10, 299-303, (In Japanese with English abstract). [CrossRef]

21. Ichinose, T.; Matsumura, K.; Nakaya, T.; Nakano, Y.; Elvidge, C.; Imhoff, M. Estimation on regional intensity of economic activity in Asia: An application of nocturnal light image by DMSP/OLS. In Proceedings of the 2nd Workshop of the EARSeL Special Interest Group on Remote Sensing for Developing Countries, Bonn, Germany, 18-20 September 2002.

22. Zhuo, L.; Ichinose, T.; Zheng, J.; Chen, J.; Shi, P.; Li, X. Modeling the population density of China at the pixel level based on DMSP/OLS non-radiance-calibrated nighttime light images. Int. J. Remote Sens. 2009, 30, 1003-1018. [CrossRef]

23. Maqsood, I.; Yemans, J.; Huang, G. Water resources management urban uncertainty: An interval-parameter fuzzy two-stage programming approach. Eur. J. Oper. Res. 2003, 167, 208-225. [CrossRef]

24. Luo, B.; Maqsood, I.; Yin, Y.; Huang, G.; Cohen, S. Adaption to climate change through water trading urban uncertainty an inexact two-stage nonlinear programming approach. J. Environ. Inf. 2003, 2, 58-68. [CrossRef]

25. Li, Y.; Huang, G.; Nie, S.; Mo, D. Interval-parameter robust quadratic programming for water quality management under uncertainty. Eng. Optim. 2008, 40, 613-635. [CrossRef]

26. Guo, P.; Huang, G.; Zhu, H.; Wang, X. A two-stage programming approach for water resources management under randomness and fuzziness. Environ. Model. Softw. 2010, 25, 1573-1581. [CrossRef]

27. Imura, H.; Onishi, A.; Okamura, M.; Fang, W. Water resource balance in Yellow River Basin based on the county level water use data. Environ. Syst. Res. 2005, 33, 477-485, (In Japanese with English abstract). [CrossRef] 
28. Imura, H.; Onishi, A. An Analysis Tool of Water Resource Management in the Yellow River Basin Based on County Level Water Budgets; IWA World Water Congress and Exhibition: Beijing, China, 2006.

29. Okamura, M.; Onishi, A.; Imura, H. Water resources supply and demand forecast in Yellow River Basin. In Proceedings of the 2nd International Workshop on Yellow River Studies, Kyoto, Japan, 8-10 November 2004; pp. 137-140.

30. Masutomi, Y.; Inui, Y.; Takahashi, K.; Matsuoka, Y. Development of highly accurate global polygonal drainage basin data. Hydrol. Process. 2009, 23, 572-584. [CrossRef]

(C) 2019 by the authors. Licensee MDPI, Basel, Switzerland. This article is an open access article distributed under the terms and conditions of the Creative Commons Attribution (CC BY) license (http://creativecommons.org/licenses/by/4.0/). 